\title{
KVALITA POŠTOVÝCH SLUŽIEB AKO PODPORNÝ FAKTOR ROZVOJA DIGITÁLNEJ EKONOMIKY
}

\author{
Mária Žilinčíková ${ }^{1}, J$ ana Štofková ${ }^{2}$
}

\begin{abstract}
The main goal of the article is to analyze the quality of the provision of postal services to legal entities through the National Postal Operator. This article focuses on the multicriteria evaluation of various criteria of customer preferences. It examines the setting up of a universal postal service with a focus on legal entities. The primary research was carried out by means of an electronic questionnaire in the conditions of the Slovak Republic. The customer segment is represented by law firms with different turnover and number of employees. Selected evaluation criteria of the National Postal Operator point to the need for modernization and more targeted settings for the delivery of letter and parcels. Nine evaluation criteria were identified. The results of this survey indicate the most suitable form of universal postal service for the selected target group.
\end{abstract}

Keywords: customer, e-commerce, pandemic, retail sale

\section{Úvod}

Globalizácia, v dôsledku ktorej sa menia environmentálne, ekonomické i sociálne podmienky, možno z tohto aspektu charakterizovat' aj ako proces neustálych zmien. Preto medzi hlavné ciele d'alšieho rozvoja priemyslu patrí hl'adanie efektívnych metód a spôsobov, ktoré by umožnili jeho adaptáciu na tieto zmeny.

Rozvoj technológií, stupňujúca sa konkurencia, neustále a často nespojité zmeny podnikatel'ského prostredia kladú vysoké nároky na manažérov všetkých organizácií, podnikov a inštitúcií. Úspešnost' plnenia náročných úloh $\mathrm{v}$ dobe globalizácie, kedy podnikatel'ské aktivity nadobúdajú nové rozmery, nezávisí len od použivaných informačných a výrobných technológií, ale v stále väčšej miere od znalostí a schopností manažérov. Úloha manažmentu je nezastupitel'ná vo všetkých organizáciách, ktoré chcú byt' úspešné. Hnacou silou zmien sa stávajú inovácie, investície do perspektívnych oblastí, najmä služieb.

$\mathrm{V}$ ekonomike dochádza $\mathrm{k}$ zmene $\mathrm{v}$ postoji organizácie pri zabezpečovaní kvality výrobkov a služieb. Kvalita prešla nad rámec predchádzajúcich spôsobov kontroly a zamerala sa na dôsledný a efektívny spôsob výkonu všetkých činností v organizácii.

Kl'účovým komponentom rozvoja znalostnej spoločnosti je rastúca dôležitost' IKT v každodennom živote. Využívanie IKT sa nestalo len každodenne využívanou a nevyhnutnou súčast'ou činností podnikov, ale aj občanov a vlád. (Štofková et al., 2015)

Doručovanie poštových zásielok sa stalo neoddelitel'nou súčast'ou fungovania právnických a fyzických osôb v Slovenskej republike. Proces distribúcie listovej a balíkovej zásielky zahŕňa mnoho čiastkových krokov, ktoré musí Národný poštový operátor logisticky,

\footnotetext{
${ }^{1}$ Ing. Mária Žilinčíková, Žilinská univerzita, Univerzitná 8215/1, 01026 Žilina, Slovensko, e-mail: maria.zilincikova@fpedas.uniza.sk

${ }^{2}$ prof. Ing. Jana Štofková, PhD., Žilinská univerzita, Univerzitná 8215/1, 01026 Žilina, Slovensko,

e-mail: jana.stofkova@fpedas.uniza.sk
} 
legislatívne a ekonomicky vhodne zvládnut' a vyriešit'. Tento proces implikuje predovšetkým univerzálnu službu.

Zákon 324/2011 o poštových službách a o zmene a doplnení niektorých zákonov je charakterizovaná univerzálna služba ako „ponuka poštových služieb, ktorá slúži na zabezpečenie minimálneho uspokojenia potrieb všetkých užívatel'ov poštových služieb na území Slovenskej republiky tak, aby bola zabezpečená dostupnost' prístupových miest verejnej poštovej siete a kontaktných miest verejnej poštovej siete, za rovnakých podmienok, v ustanovenej kvalite, za primeranú cenu, každý pracovný deň najmenej s jedným vybraním a dodaním denne". Za poskytovatel'a univerzálnych služieb sa považuje jeden alebo viac poštových podnikov, ktoré sú povinné poskytovat' univerzálnu službu na základe poštovej licencie a za podmienok a spôsobom podl'a uvedeného zákona. Univerzálna služba obsahuje:

- Výber a distribúcia poštových zásielok s hmotnost'ou do $2 \mathrm{~kg}$ vrátane.

- Výber a distribúcia slepeckých zásielok.

- Výber a distribúcia balíkov s hmotnost'ou do $10 \mathrm{~kg}$ vrátane.

- Distribúcia balíkov s hmotnost'ou do $20 \mathrm{~kg}$ vrátane, ak boli vybrané v cudzine zahraničným poskytovatel'om univerzálnej služby.

- Výber a distribúcia doporučených zásielok a poistených zásielok.

- Výber a distribúcia úradných zásielok.

- Služby späté so zapísanými poštovými zásielkami najviac v rozsahu doplnkových služieb podl'a pravidiel pre medzinárodný poštový styk.

- Vrátenie nájdenej poštovej zásielky odosielatel’ovi (Zákon o poštových službách 2019).

Univerzálna služba je poskytovaná vo vnútroštátnom poštovom styku, ako aj v medzinárodnom poštovom styku, pričom v medzinárodnom poštovom styku je umožňovaná na základe pravidiel platných pre medzinárodný poštový styk (Zákon o poštových službách 2019).

Poštová zásielka je charakterizovaná ako oznámenie v písomnej forme alebo iná vec, ktorá má byt' dodaná adresátovi, na ktorej vyznačená adresa adresáta. Finálnu podobu úpravy poštovej zásielky, v ktorej ju poštový podnik vyberá a kategorizuje, ustanoví poštový podnik v poštových podmienkach. Minimálne a maximálne rozmery poštových zásielok sú štandardizované pomocou pravidiel pre medzinárodný poštový styk.

Poštová zásielka zahŕňa:

- Listová zásielka, ktorou je predovšetkým korešpondencia, reklamná adresovaná zásielka a slepecká

- Zásielka.

- Balík.

- Periodická zásielka.

- Poštový poukaz (Zákon o poštových službách 2019).

Poštovým podnikom je náležité nazvat' podnikatel'a, ktorý poskytuje jednu alebo viacero poštových služieb alebo poštový platobný styk. Podnikanie vykonáva $\mathrm{v}$ oblasti poskytovania poštových služieb a poštového platobného styku. Poskytovat' poštové služby a poštový platobný styk je možné len za podmienok ustanovených týmto zákonom, v prípade, že:

- Univerzálna služba sa poskytuje na základe poštovej licencie.

- Poštové služby iné ako univerzálna služba a poštový platobný styk sú poskytované iba na základe registrácie a v rozsahu, rovnako v zhode so všeobecnými povoleniami.

- Poštový platobný styk poskytuje iba poštový podnik, ktorý je právnickou osobou povinne tvoriacou základné imanie (Zákon o poštových službách 2019). 


\subsection{Kvalita poskytovaných služieb}

Implementácia noriem ul’ahčuje súlad s požiadavkami stanovenými v smernici o poštových službách (EÚ 97/67/ ES), ktorej ciel'om je zaistit', aby boli v celej EÚ dostupné cenovo dostupné, vysoko kvalitné a efektívne poštové služby (cen.eu 2020).

Poštový regulačný úrad podl’a $§ 41$ zákona č. 324/2011 Z. z. o poštových službách a o zmene a doplnení niektorých zákonov (d’alej len ,zákon o poštových službách“) ustanovuje nasledujúce požiadavky na kvalitu univerzálnej služby (d’alej len ,„požiadavky“), ktoré sa dotýkajú v plnom rozsahu aj vykonávania poštového platobného styku poskytovatel'om univerzálnej služby, ak je táto povinnost' uložená v poštovej licencii (www.posta.sk 2015) .

Požiadavky sa rozlišujú na zásady na zabezpečenie kvality univerzálnej služby, základné charakteristiky kvality univerzálnej služby a ich požadované hodnoty (normy kvality) a výnimky z univerzálnej služby.

Východiskové normy kvality následne skúmajú:

- Dostupnost' prístupových a kontaktných miest verejnej poštovej siete.

- Časová dostupnost’ univerzálnej služby.

- Čas prepravy zásielok.

- Bezpečnost' zásielok.

- Informácie o univerzálnej službe.

- Vybavovanie reklamácií a st'ažností.

- Spokojnost' zákazníkov.

Poskytovatel' univerzálnej služby je zaviazaný dodržiavat' stanovené požiadavky. Rovnako sa poskytovatel' univerzálnej služby riadi STN EN pre poštové služby primerane, v záujme užívatel'ov univerzálnej služby. (Smernica 97/67/ES v platnom znení). Poštou sa na účely týchto požiadaviek determinuje:

Prístupové miesto určené na vybranie a distribúciu poštových zásielok a na predaj poštových cenín.

Kontaktné miesto, ktorým je osoba oprávnená na základe zmluvy s poskytovatel'om univerzálnej služby na vybranie poštových zásielok, výdaj odnosených alebo oznámených zásielok a na predaj poštových cenín.

Prístupové miesto alebo kontaktné miesto určené na vybranie poštových zásielok a na predaj poštových cenín (www.posta.sk 2015).

Kvalita univerzálnej poštovej služby je zachytená podl'a nasledujúcich zásad. Všetky právnické alebo fyzické osoby môžu posielat' a prijímat' poštu vo svojich domovoch alebo priestoroch najmenej pät' pracovných dní v týždni, najmenej raz denne. Ďalším pravidlom je dostatočný počet kontaktných miest a taktiež dostatočne dlhá pracovná doba pre priamu prácu s používatel'mi poštových služieb. Za nasledujúce kritérium sa považuje vhodný počet poštových schránok, vhodné časy doručenia listovej pošty prostredníctvom poštových doručovatel'ov a primerané postupy riešenia st’ažností (akos-rs.si 2020; Turská a kol. 2019).

Diagnostika čoho? však pomáha identifikovat' slabé miesto, naznačuje tiež nevyužité príležitosti. Taktiež dokáže riešit' vzniknuté problémy so zákazníkmi. Nástroje rozsiahlosti, ponúkané diagnostickou podporou riadenia kvality, je možné aplikovat' v procese, ktorý sa zameriava na plánovanie kvality služby. Okrem plánovania kvality služieb je možné jednotlivé nástroje čoho? využit' pri implementácii alebo pri hodnotení diagnostickej podpory riadenia kvality (Andriskova Strenitzerová 2014).

Pri analýze zásad na zabezpečenie kvality univerzálnej služby je potrebné sa zamerat' na úroveň zabezpečenia kvality univerzálnej služby, ktorá vychádza z týchto kritérií. Sú nimi objektívne potreby verejnosti a objektívne možnosti poskytovania univerzálnej služby. Tie sa následne delia na základe zemepisných a poveternostných podmienok, technických možností 
verejnej poštovej siete a hospodárskej únosnosti (www.posta.sk 2015; Madleňák, Madleňáková, 2020).

\section{Ciel' a metodológia}

Ciel’om predkladaného článku je analýza kvality poskytovania poštových služieb prostredníctvom Národného poštového operátora. Pre naplnenie ciel’a článku bolo potrebné teoretické vymedzenie riešenej problematiky a uskutočnenie primárneho výskumu. Uvedený článok sa v praktickej časti zameriava na právnické osoby.

Vel'kost' výberovej vzorky bola určená výpočtom vzorky pri vel'kých základných súboroch. Vzorka právnických osôb bola určená podl'a reálneho počtu právnických osôb v Slovenskej republike. Bolo potrebné realizovat' primárny výskum zameraný na spokojnost' zákazníkov s poskytovaním univerzálnej služby. Prípravná fáza výskumu zahŕňala vytvorenie plánu obsahujúceho jednotlivé špecifiká výskumu. Plán obsahuje jednotlivé kroky popísané v nasledujúcom texte. Zdrojovými údajmi pri spracovaní teoretického podkladu boli Internet, odborné a vedecké články, knižné odborné publikácie, zákony a smernice. Výskum bol kvantitatívny, jednorazový a krátkodobý. Ciel'ovou skupinou boli právnické osoby. Zdrojom údajov praktickej časti bol vytvorený dotazník. Primárne údaje boli získané na základe primárneho výskumu. Sekundárne údaje sme získali zo zverejnených údajov Štatistického úradu. Miesto zberu údajov bola Slovenská republika. Dopytovanie bolo realizované v elektronickej podobe pomocou Google formulára, ktorý bol rozosielaný emailom.

Pri metóde analýzy údajov sme spracovali nadobudnuté údaje pomocou programu Microsoft Excel. V predmetnom programe boli spracované príslušné tabul'ky a obrázky. Zber údajov bol realizovaný od 15. 09. 2020 do 14. 11. 2020. Prostredníctvom primárneho výskumu je potrebné zistit' či jednotliví respondenti (právnické osoby) sú spokojní s vybranými atribútmi kvality poskytovania univerzálnej služby Národným poštovým operátorom. V tomto prieskume sme sa zamerali predovšetkým na listové a balíkové zásielky.

Metódy, ktoré boli použité pri písaní článku sú analýza, metóda zberu informácií, primárny výskum, metódy syntézy a metóda dedukcie.

Základný súbor $(\mathrm{N})$ je rovný 248000 právnickým osobám. Výberový súbor (n) prostredníctvom výpočtov budeme zist'ovat'. Vel'kost' vzorky je počítaná s 95,5\% spol'ahlivost'ou odhadu a $\pm 6,8 \%$ maximálne prípustným rozpätím chýb. Vel'kost' vzorky sa vypočíta z celkového počtu právnických osôb využívajúcich univerzálnu poštovú službu zapojenú do prieskumu - 217. Vzhl'adom na vel'kost' základnej vzorky sme na výpočet vel'kosti základných súborov použili nasledujúci vzorec:

$$
\begin{aligned}
& n \geq t_{1-\frac{\alpha}{n} * \frac{\sigma^{n}}{\Delta^{2}}}^{2} \\
& \tau=\sqrt{p *(1-p)}
\end{aligned}
$$

Kde:

n - minimálna vel'kost' vzorky (minimálny počet respondentov).

t1- $\alpha / 2$ - spol'ahlivost' odhadu, kritická hodnota stanovená z tabuliek.

б2 - rozptyl vypočítaný zo štandardnej odchýlky.

$\Delta$ - maximálne prípustná odchýlka.

$\mathrm{N}$ - základná vel'kost' súboru.

Do vzorca dosadíme hodnoty:

$\mathrm{p}=0,5$ - pre variabilnost' základného súboru, ktoré hodnotu nepoznáme

$\mathrm{t}_{1-\alpha / 2}=2,0$ - tabul'ková hodnota pre hodnotu spol'ahlivosti 95,5\%

$\Delta$ - maximálna prípustná chybovost' predstavuje $\mp 6,8 \%$

$\sigma=$ zist'ujeme výpočtom $\mathrm{z}$ p, jedná sa o smerodajnú odchýlku 


$$
\begin{aligned}
& \sigma^{2}=\approx \sigma=\sqrt{p *(1-p)}=\sqrt{0.5 *(1-0,5)}=0,5 \\
& n \geq \frac{2,0^{0} ; 0,6^{2}}{0,0690} \geq 216,263 \text { respondentor }
\end{aligned}
$$

Minimálny počet respondentov vyplývajúci z celkového počtu právnických osôb v Slovenskej republike pri požadovanej 95,5\% spol'ahlivosti odhadu a $\mp 6,8 \%$ prípustnosti rozpätých chýb je 217, pričom tento počet tvorí reprezentatívnu vzorku právnických osôb zo Slovenskej republiky.

\section{Výsledky}

Praktická čast’ článku sa venuje vyhodnoteniu uskutočneného primárneho výskumu, ktorého ciel'om bolo zistit', akým spôsobom je potrebné zlepšit' poskytovanie univerzálnej služby v rámci pracoviska Národného poštového operátora. Primárny výskum sa zameriaval na oslovenie právnických osôb pôsobiacich na území Slovenskej republiky. Podarilo sa nám získat' odpovede od respondentov zo všetkých krajov Slovenska. Prieskumu sa zúčastnilo:

- 15 právnických osôb z Banskobystrického kraja,

- 19 právnických osôb z Bratislavského kraja,

- 83 právnických osôb z Košického kraja,

- 12 právnických osôb z Nitrianskeho kraja,

- 20 právnických osôb z Prešovského kraja,

- 12 právnických osôb z Trenčianskeho kraja,

- 17 právnických osôb z Trnavského kraja a

- 39 právnických osôb zo Žilinského kraja.

Primárnym výskumom sme chceli zároveň zistit' kol'ko právnických osôb sa zúčastnilo dopytovania na základe počtu zamestnancov (do 9 zamestnancov až po 250 zamestnancov a viac) a na základe obratu právnickej osoby (obrat menší ako 2 mil. EUR až po právnické osoby s obratom viac ako 50 mil. EUR). V rámci siete pôšt sa nachádza v Slovenskej republike 1504 pôšt. Pod skúmanou cenou zásielok rozumieme peňažnú hodnotu 1 konkrétnej listovej alebo balíkovej zásielky, ktoré zasiela predmetná právnická osoba podl’a platného cenníku Národného poštového operátora.

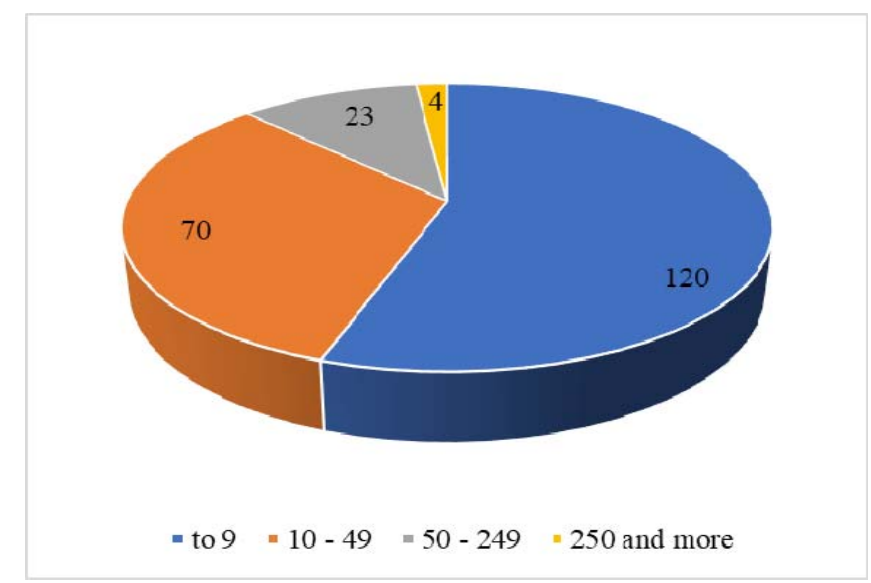

Obrázok 1. Počet oslovených právnických osôb podl’a počtu zamestnancov. 


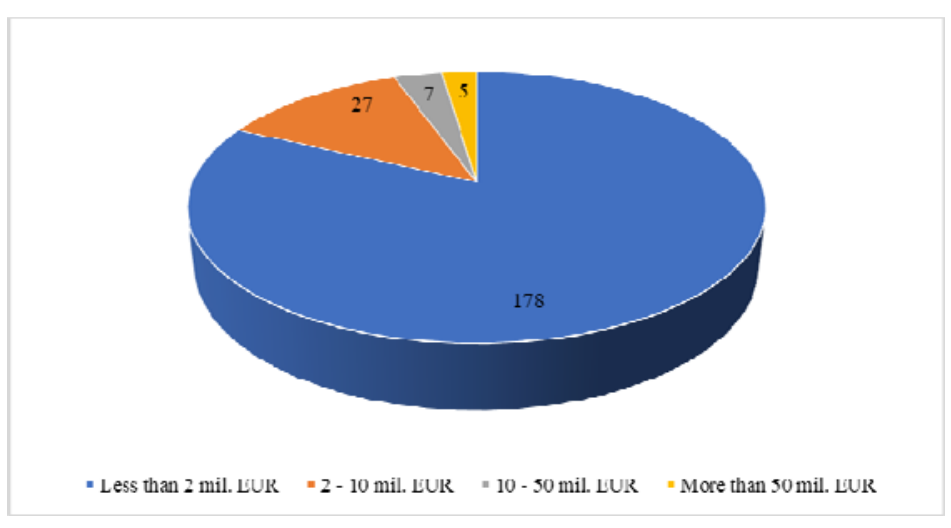

Obrázok 2. Podiel počtu oslovených právnických osôb na základe obratu danej spoločnosti.

V rámci primárneho výskumu bola formulovaná otázka nasledovne: „Ktoré kritérium je pre Vás najdôležitejšie v rámci poskytovanie služieb poskytovaných Slovenskou poštou, a. s.?"V rámci tejto otázky bola zvolená škála odpovedí, ktoré boli ohodnotené nasledovne: 1 najmenej dôležité, 2 - menej dôležité, 3 - dôležité, 4 - viac dôležité, 5 - najdôležitejšie.

Primárneho výskumu sa celkovo zúčastnilo 217 respondentov. Obrázok 3 zobrazuje odpovede respondentov ako odpovedali pri spomínanej otázke.

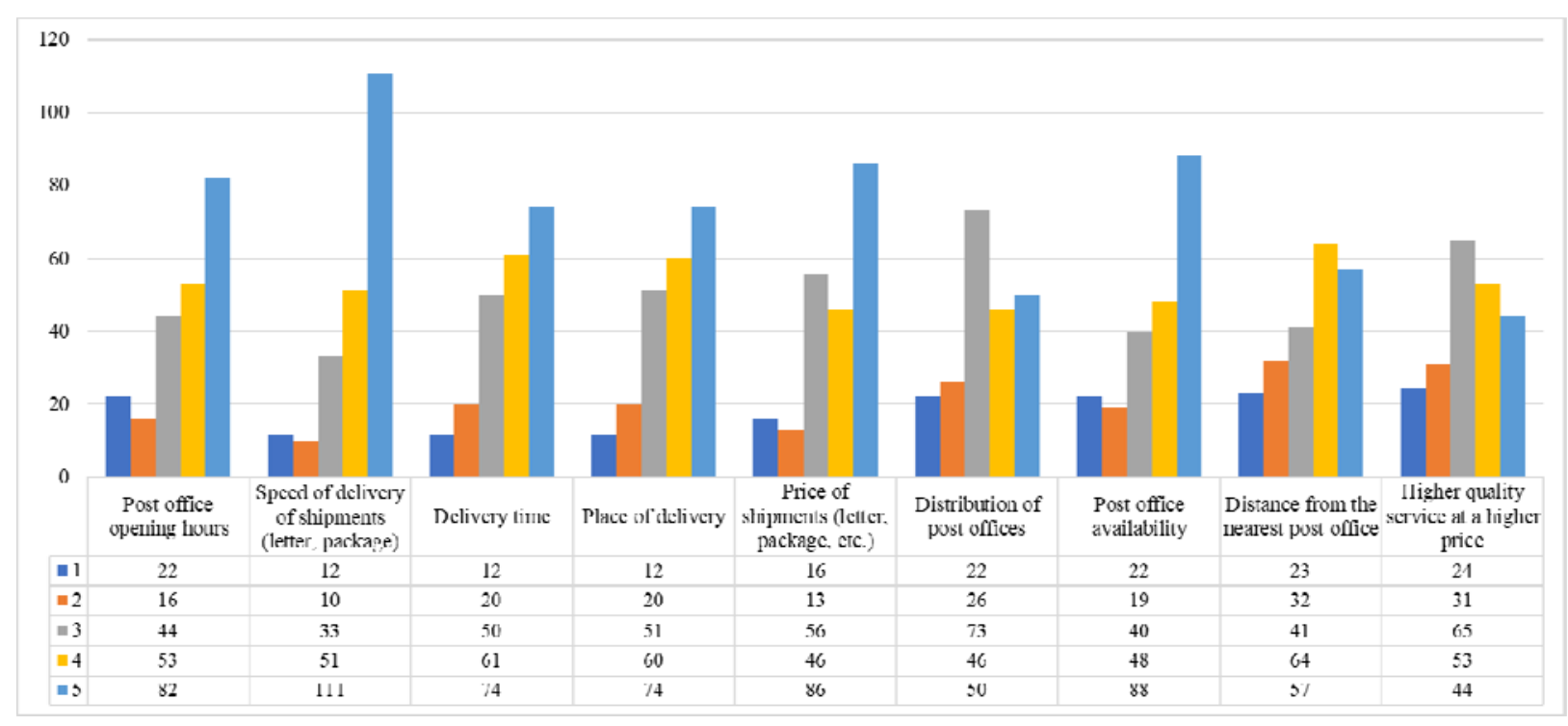

Obrázok 3. Preferencie oslovených právnických osôb.

Z pohl'adu najdôležitejších kritérií môžeme konštatovat', že z 217 respondentov je skoro pre polovicu opýtaných - 111 respondentov, najdôležitejším kritériom „Speed of delivery of shipments (letter, package)“ kritérium. Druhým kritériom je kritérium „Post office availability“, ktoré označilo až 88 respondentov a tretím v poradí je kritérium „Price of shipments (letter, package, etc.)“s 86 odpoved'ami od respondentov.

V rámci dôležitosti (známka 3), ktorú berieme ako neutrálne hodnotenie, z výsledkov primárneho výskumu sme zistili, že kritérium „Distribution of post offices“ považuje až 73 respondentov za dôležité. Kritérium „Higher quality service at a higher price“ je v poradí druhým kritériom, ktorému respondenti pridel'ujú neutrálnu dôležitost'. Až 56 respondentov označilo kritérium „Price of shipments (letter, package, etc.)“ ako tretie kritérium, ktoré berú neutrálne. 
Ked' sa pozrieme na vyhodnotenie jednotlivých kritérií z pohl'adu najmenšej dôležitosti, tak „Higher quality service at a higher price“ kritérium označilo až 24 respondentov, ktorí považujú toto kritérium za kritérium, ktoré má pre nich najmenší vplyv. Druhým v poradí je kritérium „Distance from the nearest post office“, kde túto možnost' označilo 23 respondentov. Tretím najmenej dôležitým kritériom sú pre respondentov až tri kritéria, ktoré mali zhodný počet označení od respondentov, a to 22 . Týmito kritériami sú „Post office opening hours“, „Distribution of post offices“ a „Post office availability“.

Pre lepšiu interpretáciu výsledkov uvádzame vtabul'ke 1, za každé bodové ohodnotenie, tri kritériá, ktoré dosiahli v prieskume najväčší počet odpovedí od respondentov.

Tabul'ka 1. Kritériá hodnotenia zamerané na univerzálnu poštovú službu

\begin{tabular}{|c|c|c|c|c|c|}
\hline & 5 & 4 & 3 & 2 & 1 \\
\hline $1^{\text {st }}$ & $\begin{array}{c}\text { Rýchlost' } \\
\text { doručenia } \\
\text { zásielok (list, } \\
\text { balík) }\end{array}$ & $\begin{array}{l}\text { Vzdialenost' od } \\
\text { najbližšej pošty }\end{array}$ & Distribúcia pošty & $\begin{array}{l}\text { Vzdialenost' od } \\
\text { najbližšej pošty }\end{array}$ & $\begin{array}{l}\text { Vyššia kvalita } \\
\text { služieb za vyššiu } \\
\text { cenu }\end{array}$ \\
\hline $2^{\text {nd }}$ & $\begin{array}{l}\text { Dostupnost' na } \\
\text { pošte }\end{array}$ & Dodacia lehota & $\begin{array}{c}\text { Vyššia kvalita } \\
\text { služieb za vyššiu } \\
\text { cenu }\end{array}$ & $\begin{array}{c}\text { Vyššia kvalita } \\
\text { služieb za vyššiu } \\
\text { cenu }\end{array}$ & $\begin{array}{l}\text { Vzdialenost' od } \\
\text { najbližšej pošty }\end{array}$ \\
\hline $3^{\text {rd }}$ & $\begin{array}{l}\text { Cena zásielok } \\
\text { (list, balík atd'.) }\end{array}$ & Miesto dodania & $\begin{array}{l}\text { Cena zásielok } \\
\text { (list, balík atd'.) }\end{array}$ & Distribúcia pošty & $\begin{array}{l}\text { Otváracie hodiny } \\
\text { pošty } \\
\text { Distribúcia pôšt } \\
\text { Dostupnost' na } \\
\text { pošte }\end{array}$ \\
\hline
\end{tabular}

Nakol'ko spokojnost' právnických osôb s poskytovaním univerzálnej služby závisí v najväčšej miere od kritéria „Speed of delivery of shipments (letter, package)“ zamerali sme sa na konkretizáciu vyhovujúcich atribútov daného kritéria. Doplňujúcou otázkou prieskumu bola otázka: „Ste spokojný s rýchlost’ou dodávania listových zásielok?“ Respondenti odpovedali na položenú otázku ,áno“ alebo „nie“. Všetci respondenti sa v danej otázke vyjadrili kladnou odpoved'ou. $Z$ výsledkov vyplýva, že nastavenie rýchlosti listových zásielok pre právnické osoby je pre nich $\mathrm{z}$ ich pohl'adu vyhovujúce.

$\mathrm{V}$ rámci primárneho výskumu bola formulovaná d’alšia nadväzujúca otázka, ktorá znela nasledovne: „V prípade, ak by rýchlost' dodávania balíkov nebola kvantifikovaná, ako rýchlo by ste požadovali, aby Vám boli balíky dodané odo dňa odoslania konkrétneho balíka?" V danej otázke bola zvolená škála odpovedí 2 dni odo dňa odoslania, 3 dni odo dňa odoslania, 4 dni odo dňa odoslania, najneskôr do 1 týždňa. V nasledujúcom obrázku je zobrazená preferencia počtu dní pri balíkových zásielkach.

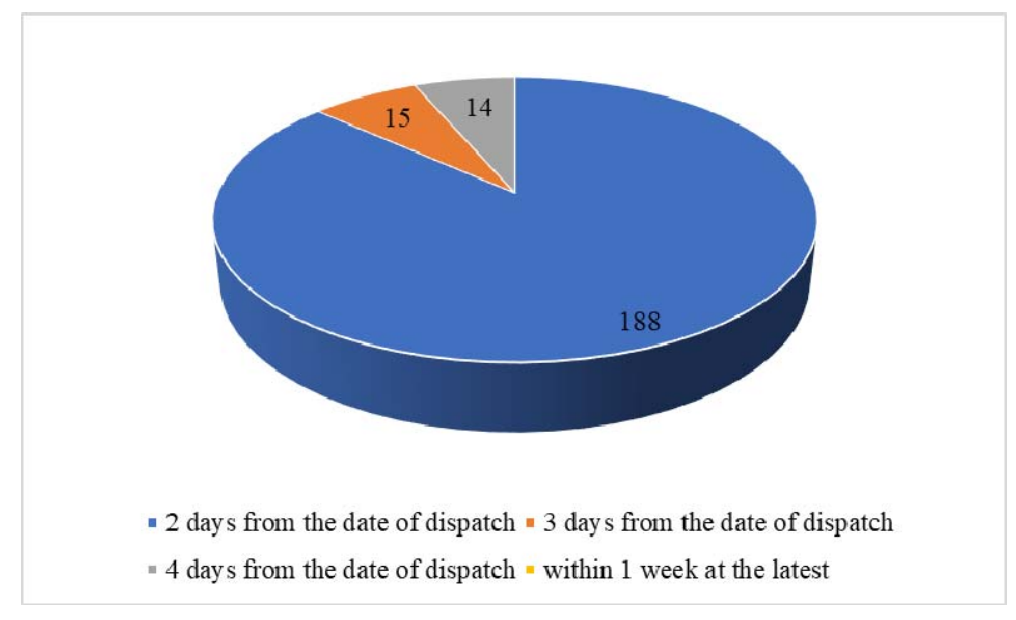

Obrázok 4. Čas doručenia balíkovej zásielky právnickej osobe 
Z výsledkov uvedených na obrázku vyplýva, že až 188 právnických osôb by požadovalo, aby im bol balík doručený do 2 dní odo dňa odoslania. Z 217 respondentov skupina 15 respondentov označila možnost' 3 dni odo dňa odoslania a 14 respondentov označilo možnost' 4 dni odo dňa doručenia. Nenašla sa ani jedna právnická osoba, ktorá by požadovala dodanie balíka najneskôr do týždňa. Môžeme teda konštatovat', že pre právnické osoby je čas doručenia balíkov dôležitým kritériom.

\section{Záver}

K najdôležitejším zložkám procesu poskytovania univerzálnej poštovej služby patrí doručovanie poštových zásielok. Národný poštový operátor vykonáva rozmiestnenie a dostupnost' pôšt pre koncového zákazníka, aby uspokojil jeho potreby a požiadavky, ktoré má koncový zákazník. Procesy, týkajúce sa univerzálnej poštovej služby, optimalizuje Národný poštový operátor za účelom zachovania efektívnosti doručovania poštových zásielok.

Najvyšší počet respondentov, a to 111 respondentov, označilo rýchlost' dodania zásielok ako najdôležitejšie kritérium preferencie poskytovania univerzálnej poštovej služby. Nasleduje dostupnost' pošty s 88 respondentami, cena zásielok s 86 respondentami a 82 respondentov signovalo najdôležitejším otváracie hodiny pošty.

$\mathrm{V}$ rámci fungovania právnických osôb $\mathrm{s}$ ohl'adom na potrebu zrýchlenia procesu odosielania a doručovania listov a balíkov, je možné konštatovat', že cena nezohráva hlavnú úlohu pri spokojnosti zákazníka. Rozhodovacie kritérium pri výbere poštovej služby najmenej ovplyvňuje atribút vyššia kvalita služby za vyššiu cenu, ale aj nasledujúce atribúty, a to rozmiestnenie pôšt a vzdialenost' od najbližšej pošty. Priemerné hodnoty dosiahli kritériá hodnotenia čas dodania zásielok a miesto dodania zásielok. Nastavenie rýchlosti dodávania listových zásielok pre právnické osoby je vyhovujúce.

Uvedený výskum odporúča optimalizovat' rýchlost' doručovania balíkových zásielok v prípade zákazníkov, konkrétne právnických osôb.

\section{Literatúra}

[1] AKOS, 2019. Quality of universal postal service. Available online: https://www.akosrs.si/en/post/explore/quality-of-universal-postal-service

[2] Andriskova, I., Strenitzerova,M., 2014, The diagnostic support tool-quality function deployment and its implementation possibilities to urban public transport quality management. In: Communications: scientific letters of the University of Žilina. - ISSN 1335-4205. - Vol. 16, no. 2 (2014), s. 63-69.

[3] CEN, 2020, Postal service standards improve service delivery in the Digital Single Market. Available online: https://www.cen.eu/news/brief-news/Pages/NEWS-2019033.aspx

[4] Madleňák, R., \& Madleňáková, L., 2020, Multi-criteria evaluation of e-shop methods of delivery from the customer's perspective. In: Transport Problems. - ISSN 2300-861X. Vol, 15, no. 3 (2020), s. 5-14.

[5] MDPT SR, 2014, Požiadavky na kvalitu univerzálnej služby. Available online: https://www.posta.sk/subory/561/poziadavky-na-kvalitu-2009.pdf

[6] Štofková, J. et al. Business Management. Bratislava: Dolis, 2015.

[7] Turská, S., Chinoracký, R., Madleňáková, L., \& Čorejová, T. Optimization of the Delivery Process in the Urban Area 
[8] Úradný vestník európskych spoločenstiev, 1997, Smernica európskeho parlamentu a rady 97/67/ES. Available online: https:/eur-lex.europa.eu/legal-content/SK/TXT/PDF/?uri $=$ CELEX:31997L0067\&from $=\mathrm{EN}$

[9] Zákon 324/2011 Z.z. o poštových službách a o zmene a doplnení niektorých zákonov. Available online: https://www.posta.sk/subory/562/zakon-o-postovych-sluzbach.pdf

\section{Grantová podpora}

Táto publikácia vznikla vd’aka podpore projektu VEGA 1/0518/19. 